\title{
Pengaruh Pembiayaan Mudharabah, Murabahah dan Musyarakah terhadap Return On Assets
}

\author{
Irvan Muhamad Rizky*, Azib
}

Prodi Manajemen, Fakultas Ekonomi dan Bisnis, Universitas Islam Bandung, Indonesia.

*irvanmr7@gmail.com, azib_asroi@yahoo.com

\begin{abstract}
Mudharabah, Murabahah and Musyarakah Against ROA on Sharia Purchases listed on the Indonesia Stock Exchange. The data in this study are quarterly financial statements at Bank Rakyat Indonesia Syariah with a purposive sampling technique and obtained research samples of 6 samples of 30 data. For the dependent variable $(\mathrm{Y})$ of this study is Return On Assets (ROA). For independent variables (X) published: Murabahah, Mudharabah, and Musyarakah. The method used is a quantitative research method. For the data source is secondary data using SPSS 20.0 data processing analysis. Based on the results of multiple regression analysis, the results of this study indicate that Murabahah and Mudharabah have a positive and significant effect on Return On Assets (ROA), Musyarakah have a negative and significant effect on Return On Assets (ROA), and Inflation does not play a role on Return On Assets (ROA).
\end{abstract}

Keywords: Mudhabarah, Murabaha, Musyarakah and ROA

Abstrak. Penelitian ini bertujuan untuk mengetahui apakah, Mudharabah, Murabahah dan Musyarakah Terhadap ROA pada Perbankan Syariah yang terdaftar di Bursa Efek Indonesia. Data dalam penelitian ini adalah laporan keuangan triwulan pada Bank Rakyat Indonesia Syariah dengan teknik purposive sampling dan diperoleh sampel penelitian sebanyak 6 sampel 30 data. Untuk variabel dependen (Y) dari penelitian ini adalah Return On Asset (ROA). Untuk variabel independen (X) meliputi: Murabahah, Mudharabah, dan Musyarakah. Metode yang digunakan adalah metode penelitian kuantitatif. Untuk sumber data adalah data sekunder dengan menggunakan analisis pengolahan data SPSS 20.0. Berdasarkan hasil analisis regresi berganda, maka hasil penelitian ini menunjukkan bahwa Murabahah dan Mudharabah berpengaruh positif dan signifikan terhadap Return On Asset (ROA), Musyarakah berpengaruh negatif dan signifikan terhadap Return On Asset (ROA), dan Inflasi tidak berpengaruh terhadap Return On Asset (ROA).

Kata Kunci: Mudhabarah, Murabahah, Musyarakah dan ROA 


\section{A. Pendahuluan}

Pada zaman milenial ini perekonomian semakin modern sehingga uang menjadi peranan penting bagi seluruh kebutuhan masyarakat. Uang kini bukan hanya sekedar alat pembayaran namun uang dapat menjadi tolak ukur kekayaan pada setiap orang. Dan uang menjadi kebutuhan utama bahkan uang menjadi penentu stabilitas dan kemajuan perekonomian. Sekarang banyak berdirinya Bank Syariah akibat desakan masyarakat muslim yang ingin menyimpan uangnya dibank tetapi tidak ingin menimbulkan unsur riba. Sekarang ini perbankan yang berkembang di Indonesia ada dua yaitu perbankan konvensional dan perbankan syariah. Bank konvensional menurut undang-undang No. 10 tahun 1999 tentang perbankan adalah badan usaha yang menghimpun dana dari masyarakat dalam bentuk simpanan dan menyalurkan kepada masyarakat dalam bentuk kredit dan atau bentuk-bentuk lainnya dalam rangka meningkatkan taraf rakyat banyak.

Adaya larangan riba dalam islam membuat Bank Syariah menjadi pedoman dalam melaksanakan kegiatan usaha bisnis ini, sehingga harus adanya perjanjian antara bank dan nasabah mengenai utang piutang agar terbebas dari bunga. Islam yang bertujuan untuk mengembangkan sistem dan nilai dan etika, islam dalam paradigma dan prakteknya dibidang ekonomi.

Perbankan Syariah mempunyai fungsi yang sama dengan perbankan konvensional, yaitu sebagai Lembaga intermediasi (penyaluran), dari nasabah yang mempunyai dana dengan nasabah yang membutuhkan dana. Namun, nasabah yang memiliki dana dan menyimpan di Bank Syariah diperlakukan layaknya investor. Dana yang telah disimpan di Bank Syrariah dapat disalurkan kepada nasabah dalam bentuk pembiayaan untuk beragam, baik produktif (investasi dan modal kerja) maupun konsumtif. Dari pembiayaan tersebut, Bank Syariah akan memperoleh bagi hasil yang merupakan pendapatan bagi bank Syariah. Nasabah pembiayaan akan membayar pokok ditambah bagi hasil kepada bank Syariah. Pokok akan dikembalikan kepada pemilik dana sedangkan bagi hasil akan dibagi hasilkan antara bank Syariah dan nasabah dana sesuai dengan nisbah yang telah disepakati.

Berawal dari akuisisi PT. Bank Rakyat Indonesia (Persero), Tbk., terhadap Bank Jasa Arta pada 19 Desember 2007 dan setelah mendapatkan izin dari Bank Indonesia pada 16 Oktober 2008 melalui suratnya o.10/67/KEP.GBI/DpG/2008, maka pada tanggal 17 November 2008 PT Bank BRIsyariah Tbk secara resmi beroperasi. Kemudian PT Bank BRIsyariah Tbk merubah kegiatan usaha yang semula beroperasional secara konvensional, kemudian diubah menjadi kegiatan perbankan berdasarkan prinsip syariah Islam.Saat ini PT Bank BRIsyariah Tbk menjadi bank syariah ketiga terbesar berdasarkan aset. PT Bank BRIsyariah Tbk tumbuh dengan pesat baik dari sisi aset, jumlah pembiayaan dan perolehan dana pihak ketiga. Dengan berfokus pada segmen menengah bawah, PT Bank BRIsyariah Tbk menargetkan menjadi bank ritel modern terkemuka dengan berbagai ragam produk dan layanan perbankan.

Pembiayaan yang ditawarkan oleh bank syariah tidak hanya diselesaikan dengan akad mudharabah dan musyarakah. Tetapi, bank syariah juga dapat melakukan pembiayaan dengan akad jual beli dan sewa. Dengan akad jual beli dan sewa, bank syariah akan memperoleh pendapatan yang bersifat lebih pasti. Secara umum akad jual beli dan sewa dalam perbankan syariah adalah murabahah, ba'i salam, ba'i istisna, ijarah dan ijarah wa iqtina.

Murabahah adalah jual beli barang pada harga asal dengan tambahan keuntungan yang disepakati. Dalam murabahah penjual harus memberi harga produk yang ia beli dan menentukan suatu tingkat keuntungan tambahannya (Antonio, 2008). Sedangkan akad murabahah menurut Yuliarmi dan Yoga dalah jual beli barang dengan alat tukar disertai tambahan yang telah ditentukan (resale with a stated profit). Pembiayaan murabahah pada perbankan syariah yakni bank syariah bertindak sebagai penjual, sedangkan nasabah bertindak sebagai pembeli.

Menurut media cetak yang di terbitkan kontan.co.id. Kemampuan Bank Umum Syariah (BUS) dalam mencetak laba masih mini. Data Otoritas Jasa Keuangan (OJK) rasio pendapatan bersih yang diperoleh dari total asset alias Return on Asset (ROA) masih rendah.

Seperti kasus Bank BRI Syariah Tbk memiliki ROA sebesar 0,92\%. Sekertaris Bank 
BRI Syariah Indri Tri Handayani menyatakan, Hingga akhir 2018 BRI Syariah berupaya mningkatkan ROA diangka 0,97\%. Strategi BRI Syariah diantara lain meningkatkan pertumbuhan pembiayaan pada segmen consumer. Ini melalui beberapa skema pembiayaan seperti Kredit Pemilikan Rumah (KPR) dan pembiayaan multiguna.

Selain itu upaya yang akan dilakukan Bank BRI Syariah dengan meningkatkan pembiayaan komersial melalui kerjasama sinergi dengan induk usaha yakni PT Bank Rakyat Indonesia. Selain itu Bank BRI Syariah membutuhkan laba bersih setelah pajak tumbuh $70 \%$ secara year on year (yoy) menjadi Rp120,157 miliar. Total asset mengalami kenaikan sebesar 20,87\% yoy menjadi Rp 36,14 triliun dari sebelumnya Rp29,9 triliun pada juni 2017.

\section{B. Landasan Teori}

\section{Bank Syariah}

Bank islam atau sering disebut dengan bank syariah adalah bank yang beroperasi tanpa mengandalkan bunga. Bank syariah juga dapat diartikan sebagai lembaga keuangan atau perbankan yang operasional dan roduknya dikengkan berdasarkan Al Qur'an dan Hadist. Antonio dan Perwanta atmadja membedakan dua pengertian yaitu bank islam dan bank yang beroperasi dengan prinsip syariat islam.

Bank islam adalah bank yang beroperasi dengan prinsip yang sesuai dengan syariat islam dan tata cara beroperasinya mengacu pada ketentuan-ketentuan Al Qur'an dan Hadist. Adapun bank yang beroperasi sesuai dengan prinsi islam adalah bank yang dalam operasinya mengikuti ketentuan-ketentuan syariat islam, khususnya yang menyangkut tata cara bermuamalat secara islam.

Bank syariah merupakan salah satu bentuk dari perbankan nasional yang mendasarkan operasionalnya pada syariat atau hukum islam. Menurut Schaik (2001), bank islam merupakan sbuah bentuk dari bank modern yang di dasarkan pada hukum islam yang sah, dikembangakan pada abad pertama islam, dan meniadakan keuangan berdasarkan keastian serta keuntungan yang ditentukan sebelumnya.

Sudarsono (2004) mengemukakan bahwa bank syariah merupakan lembaga keuangan yang usaha pokoknya memberikan pembiayaan dan jasa-jasa lain dalam lalu lintas pembayaran serta peredaran uang yang beroperasi dengan prinsi-prinsip islam. Adapun definisi bank menurut Muhammad (2002) dan Donna (2006) adalah lembaga keuangan yang beroperasi tanpa mengandalkan bunga dan usaha pokoknya memberikan pembiayaan dan jasajasa lainnya dalam lalu lintas pembayaran serta peredaran uamg yang pengoperasiannya sesuai dengan prinsip islam. Dalam undang-undang No.21 tahun 2008 tentang perbankan syariah pasal satu (1) disebutkan bahwa perbankan syariah adalah segala sesuatu yang menyangkut perbankan syariah dan unit usaha syariah mencakup kelembagaan, kegiatan usaha, serta cara dan proses dalam melaksanakan kegiatan usahanya. Bank syariah dikembangkan sebagai lembaga bisnis keuangan yang melaksanakan kgiatan usahanya sejalan dengan prinsip-prinip dasar dalam ekonomi islam.

\section{Pembiayaan}

Pembiayaan (financing) adalah pendanaan yang diberikan oleh suatu pihak kepada pihak lain untuk mendukung investasi yang telah direncanakan, baik yang dilakukan sendiri maupun lembaga. Menurut Muhammad (2005:17), secara umum tujuan pembiayaan dibedakan menjadi dua kelompok yaitu pembiayaan tingkat makro dan tujuan pembiayaan tingkat mikro. Setiap konsumen mendapatkan pendapatan, konsumen memiliki dua pilihan yakni, semua pendapatannya digunakan untuk berkonsumsi atau disimpan di bank (meminjamkannya ke bank). Pilihan ini bisa ditentukan dari berapa imbal hasil yang akan ia terima. Jika imbal hasil yang ditawarkan oleh bank menguntungkan kosnumen, maka dia akan memilih untuk menyimpan uangnya di bank dengan kata lain dia meminjamkan uangnya di bank. Hal sebaliknya jika imbal hasil yang ditawarkan tidak menguntungkan menurut konsumen maka dia akan memilih untuk menggunakan pendapatannya untuk berkonsumsi.

Dalam masyarakat Indonesia, selain dikenal istilah utang-piutang, juga dikenal istilah kredit dalam perbankan konvensional dan istilah pembiayaan dalam perbankan 
syari'ah. Utang-piutang biasanya digunakan oleh masyarakat dalam konteks pemberian pinjaman kepada pihak lain. Seseorang yang meminjamkan hartanya kepada orang lain, maka ia dapat disebut telah memberikan utang kepadanya. Adapun istilah kredit atau pembiayaan lebih banyak digunakan oleh masyarakat pada transaksi perbankan dan pembelian yang tidak dibayar secara tunai. Secara esensial, antara utang dan kredit atau pembiyaan tidak jauh berbeda dalam pemaknaannya di masyarakat. Pembiayaan atau financing ialah pendanaan yang diberikan oleh suatu pihak kepada pihak lain untuk mendukung investasi yang telah direncanakan, baik dilakukan sendiri maupun lembaga. Dengan kata lain, pembiayaan adalah pendanaan yang dikeluarkan untuk mendukung investasi yang telah direncanakan.

\section{Mudharabah}

Mudharabah, atau kemitraan pasif, adalah kontrak untuk pembiayaan dengan struktur persekutuan atau kongsi. Pemilik modal atau shahibul mal sebagai mitra pasif, menanamkan modalnya pada suatu atau beberapa bentuk usaha yang ditentukan (muqayyadah atau restricted) atau tidak ditentukan (mutlaqah atau unrestricted), dengan pihak lain yang merupakan pengusaha sebagai pengelola modal, atau disebut sebagai mudharib. Terhadap harta shahibul mal, mudharib bertindak sebagai wakil atas dasar trust atau kepercayaan; sedangkan dari segi perolehan keuntungan, mudharib berfungsi sebagai mitra.

Status dana untuk dijadikan modal dari shahibul mal dipersamakan dengan modal yang ada pada manusia atau human capital, yang berupa keahlian berbisnis dari mudharib. Keahlian berbisnis ini meliputi pengetahuan, pengalaman, ide yang kreatif, yang semuanya tercatat dalam suatu jejak rekam yang berkaitan pada suatu jenis bisnis atau usaha. Modal harus disetor tunai atau tidak boleh diutang oleh shahibul mal, sedangkan mudharib memberikan kontribusinya dalam bentuk usaha dan keahlian berbisnisnya.

\section{Murabahah}

Murabahah adalah suatu bentuk jual beli tertentu ketika penjual menyatakan biaya perolehan barang, meliputi harga dan biaya-biaya lain yang dikeluarkan untuk memperoleh barang tersebut, dan tingkat keuntungan (margin) yang diinginkan Dalam praktik pembiayaan berdasarkan akad murabahah, bank tidak menerima penyerahan barang atau dengan kata lain barang diserahkan langsung oleh penjual atau produsen kepada nasabah penerima fasilitas (Ascarya, 2015:81). Murabahah adalah transaksi jual beli dimana bank menyebut jumlah keuntungannya. Bank bertindak sebagai penjual, sementara nasabah sebagai pembeli. Harga jual adalah harga beli bank dari pemasok ditambah keuntungan (margin). Kedua belah pihak harus menyepakati harga jual dan jangka waktu pembayaran. Harga jual dicantumkan dalam akad jual beli dan jika telah disepakati tidak dapat berubah selama berlakunya akad. Dalam perbankan, murabahah selalu dilakukan dengan cara pembayaran cicilan (bi'tsaman ajil, atau muajjal). Dalam transaksi ini barang diserahkan segera setelah akad, sementara pembayaran dilakukan secara tangguh/cicilan (Karim, 2014: 98).

\section{Musyarakah}

Musyarakah adalah pembiayaan ekuitas melalui kerja sama atau joint venture menyerupai venture capital pada pembiayaan konvensional; dan dilakukan untuk jangka waktu tertentu, dan dapat diperpanjang jika di kehendaki oleh para pihak. Perbedaan dengan akad mudharabah adalah pada akad musyaraka, setiap pihak yang terdiri dari dua atau lebih pengusaha masingmasing memberikan kontribusi, dalam modal, aspek manajemen, dan pengawasan, baik dalam porsi yang berbeda maupun sama, atas kesepakatan awal. Para mitra memiliki hak suara secara proporsional berdasarkan modal masing- masing, dan setiap wakil dapat duduk dalam pengelolaan usaha. Setiap mitra bekerja sama atas "kepercayaan", dan tidak dapat meminta jaminan dari mitra lainnya. Pengambilan keputusan usaha dilakukan bersama-sama, atas dasar kontribusi modal maaing-masing. Dengan demikian, setiap mitra dapat menentukan arah perkembangan usaha, dan sekaligus secara bersama-sama dapat mengontrol berjalannya usaha.

Akad Syirkah pada perbankan syariah diaplikasikan dalam bentuk pembiayaan almusyarakah. Pembiayaan al-musyarakah ini disalurkan untuk membiayai sebuah proyek. Nasabah dan bank sama-sama meyediakan dana untuk membiayai proyek tersebut. Setelah proyek itu selesai, nasabah mengembalikan dana tersebut kepada bank sekaligus dengan bagi 
hasil yang telah disepakati. Pembiayaan musyarakah di perbankan syariah bisa diberikan dalam berbagai bentuk, diantaranya:

1. Musyarakah permanen (Continous Musyarakah), dimana pihak bank merupakan partner tetap dalam suatu proyek atau usaha.

2. Musyarakah yang digunakan untuk pembiayaan modal kerja (working capital), dimana ban merupakan partner pada tahap awal dari sebuah usaha atau proses produksi.

Musyarakah yang digunakan untuk pembiayaan jangka pendek. Musyarakah jenis ini bisa diaplikasikan dalam bentuk project finance atau pembiayaan perdagangan, sepertu ekspor, impor, penyediaan bahan mentah atau keperluan- keperluan khusus nasabah lainnya. Bentuk kedua dari musyarakah in dikenal dengan Musyarakah Mutanaqishah yang berarti bentuk kerja sama antara dua pihak atau lebih untuk kepemilikan suatu barang atau aset. akad Musyarakah Mutanaqishah terdiri dari akad musyarakah syirkah dan bai' (jual-beli).

\section{Landasan Murabahah}

Tabel 1. Landasan Murabahah

\begin{tabular}{|c|c|c|l|}
\hline No. & SURAT & AYAT & \multicolumn{2}{|c|}{ ARTINYA } \\
\hline 1. & Al-Baqarah & 275 & $\begin{array}{l}\text { ". . .dan Allah telah } \\
\text { menghalalkan jual beli dan } \\
\text { mengaharamkan riba." }\end{array}$ \\
\hline 2. & Al-Maidah & 1 & $\begin{array}{l}\text { ". . .hai orang yang } \\
\text { beriman! Penuhilah akad-akad } \\
\text { itu..." }\end{array}$ \\
\hline 3. & Al-Baqarah & 280 & $\begin{array}{l}\text { itu) "dan jika (orang berutang } \\
\text { dalam kesukaran, maka } \\
\text { berkelapangan. . . sampai ia }\end{array}$ \\
\hline
\end{tabular}

Hubungan antara Pembiayaan Mudharabah dengan Return on Asset

Murabahah yaitu akad jual beli atas barang tertentu, dimana penjual menyebutkan harga pembelian barang kepada pembeli kemudian menjual kepada pihak pembeli dengan mensyaratkan keuntungan yang di harapkan sesuai jumlah tertentu. Dalam akad murabahah penjual menjual barangnya dengan meminta kelebihan atas harga beli dengan harga jual. Perbedaan antara harga beli dan harga jual barang disebut margin keuntungan (Ismail, 2011:138). Pendapatan murabahah memiliki pengaruh besar terhadap perubahan tingkat profitabilitas (ROA). Artinya, Semakin tinggi pembiayaan murabahah, maka akan menghasilkan pendapatan yang tinggi sehingga akan mempengaruhi laba yang meningkat juga.

\section{Hubungan antara Pembiayaan Murabahah Terhadap Return On Asset (ROA)}

Pengelolaan pembiayaan muruabahah akan menghasilkan pendapatan berupa nisbah. Dengan diperolehnya nisbah tersebut, maka akan mempengaruhi besarnya laba yang diperoleh bank syariah, dimana semakin tinggi pendapatan atau pembiayaan mudharabah yang diberikan bank untuk penyaluran dana, maka semakin tinggi pula tingkat Return On Asset yang diperoleh oleh bank tersebut (Chalifah, 2015:34). Artinya Semakin tinggi pembiayaan mudharabah, maka akan menghasilkan pendapatan yang tinggi sehingga akan mempengaruhi laba yang meningkat juga.

\section{Hubungan antara Pembiayaan Musyarakah terhadap Return On Asset (ROA)}

Pengelolaan pembiayaan musyarakah akan menghasilkan pendapatan berupa nisbah. Dengan diperolehnya nisbah tersebut, maka akan mempengaruhi besarnya laba yang diperoleh bank 
syariah, dimana semakin tinggi pendapatan atau pembiayaan musyarakah yang diberikan bank untuk penyaluran dana, maka semakin tinggi pula tingkat Return On Asset yang di peroleh oleh bank tersebut (Chalifah, 2015: 35). Artinya Semakin tinggi pembiayaan musyarakah, maka akan menghasilkan pendapatan yang tinggi sehingga akan mempengaruhi laba yang meningkat juga.

\section{Hipotesis}

$\mathrm{H}_{1}$ : Terdapat pengaruh Mudharabah secara signifikan terhadap Return on Asset pada perbankan Bank BRI Syariah tahun 2012-2019.

$\mathrm{H}_{2}$ : Terdapat pengaruh Murabahah secara signifikan terhadap Return on Asset pada perbankan Bank BRI Syariah tahun 2012-2019.

$\mathrm{H}_{3}$ : Terdapat pengaruh Musyarakah secara signifikan terhadap Return on Asset pada perbankan Bank BRI Syariah tahun 2012-2019.

\section{Metode Penelitian}

Metode penelitian yang digunakan adalah metode deskriptif dan verifikatif. Menurut Sugiyono (2013:207) penelitian deskriptif adalah penelitian yang dilakukan untuk mengetahui nilai variabel mandiri, baik satu variabel atau lebih (independen) tanpa membuat perbandingan, atau menghubungkan dengan variabel yang lain yang diteliti dan di analisis sehingga menghasilkan kesimpulan. Sedangkan penelitian verifikatif pada dasarnya untuk menguji teori dengan pengujian hipotesis. Pengujian hipotesis dilakukan dengan menggunakan perhitungan statistik yang digunakan untuk menguji variabel independent terhadap variabel dependent yang diteliti. Verifikatif berarti menguji teori dengan pengujian suatu hipotesis apakah diterima atau ditolak.

Dalam penelitian ini metode deskriptif digunakan untuk menggambarkan tentang variabel mudhabarah, murabahah dan musyarakah terhadap return on asset. Sedangkan metode verifikatif digunakan untuk menjawab hipotesis ada atau tidak adanya pengaruh mudharabah,murabahah dan musyarakah terhadap Return on Asset baik secara parsial maupun secara simultan.

\section{Hasil Penelitian dan Pembahasan}

Tabel 2. Regresi Berganda

Coefficients $^{\mathrm{a}}$

\begin{tabular}{|c|c|c|c|c|c|}
\hline \multirow{2}{*}{ Model } & \multicolumn{2}{|c|}{$\begin{array}{l}\text { Unstandardized } \\
\text { Coefficients }\end{array}$} & \multirow{2}{*}{$\begin{array}{c}\begin{array}{c}\text { Standar } \\
\text { dized } \\
\text { Coeffic } \\
\text { ients }\end{array} \\
\text { Beta }\end{array}$} & \multirow{2}{*}{$\mathrm{t}$} & \multirow{2}{*}{ Sig. } \\
\hline & B & $\begin{array}{l}\text { Std. } \\
\text { Error }\end{array}$ & & & \\
\hline (Constant) & .928 & .159 & & 5.848 & .000 \\
\hline MUSYARAKAH & 4.119E-007 & .000 & .156 & .489 & .629 \\
\hline MUDHABARAH & $1.200 \mathrm{E}-005$ & .000 & 1.184 & 2.417 & .023 \\
\hline MURABAHAH & $-1.348 \mathrm{E}-006$ & .000 & -1.345 & -2.132 & .043 \\
\hline
\end{tabular}

Berdasarkan Tabel 2. diatas, maka didapatlah persamaan regresi sebagai berikut :

Return on Asset $=0,928+4.119 \mathrm{E}-007$ (MUSYARAKAH) + 1.200E-005 


\section{(MURABAHAH) + -1348E-006 (MUDHARABAH)}

Keterangan :

1. Nilai konstanta sebesar 0,928 menunjukan bahwa apabila nilai independent (Musyarakah,Murabahah dan Mudharabah) adalah 0 maka return saham (Ri) adalah sebesar 0,928

2. Nilai koefisien regresi variabel mudharabah sebagai variabel $X 1$ yaitu sebesar $-1.348 \mathrm{E}$ 006. Hal ini mengandung arti bahwa setiap kenaikan Mudharabah sebesar 1 satuan maka return saham akan naik sebesar -1.348E-006 dengan asumsi bahwa variabel independen lainnya (Murabahah dan Musyarakah) adalah tetap atau bernilai 0 (nol).

3. Nilai koefisien regresi variabel murabahah sebagai variabel $X 2$ yaitu sebesar $1.200 \mathrm{E}$ 005. Hal ini mengandung arti bahwa setiap kenaikan Murabahah sebesar 1 satuan maka return saham akan naik sebesar 1.200E-005 dengan asumsi bahwa variabel independen lainnya (Mudharabah dan Musyarakah) adalah tetap atau bernilai 0 (nol).

4. Nilai koefisien regresi variabel musyarakah sebagai variabel $X 3$ yaitu sebesar 4.119E007. Hal ini mengandung arti bahwa setiap kenaikan Musyarakah sebesar 1 satuan maka return saham akan naik sebesar 4.119E-007 dengan asumsi bahwa variabel

\section{Uji Simultan (F)} independen lainnya (Mudarabah dan Murabahah) adalah tetap atau bernilai 0 (nol).

Uji $\mathrm{F}$ bertujuan untuk mengetahui variabel independen secara simultan terhadap variabel dependen. Uji F ini merupakan tahapan awal mengidentifikasi model regresi yang diestimasi layak atau tidak. Pengambilan keputusan berdasarkan probabilitas adalah sebagai berikut :

1. Bila nilai signifikasi t dari mudharabah, murabahah dan musyarakah lebih besar dari $\alpha$ = 0,10 maka H0 diterima dan Ha ditolak.

2. Bila nilai signifikasi t dari mudharabah, murabahah dan musyarakah lebih kecil dari $\alpha$ = 0,10 maka H0 ditolak dan Ha diterima.

Tabel 3. Uji F

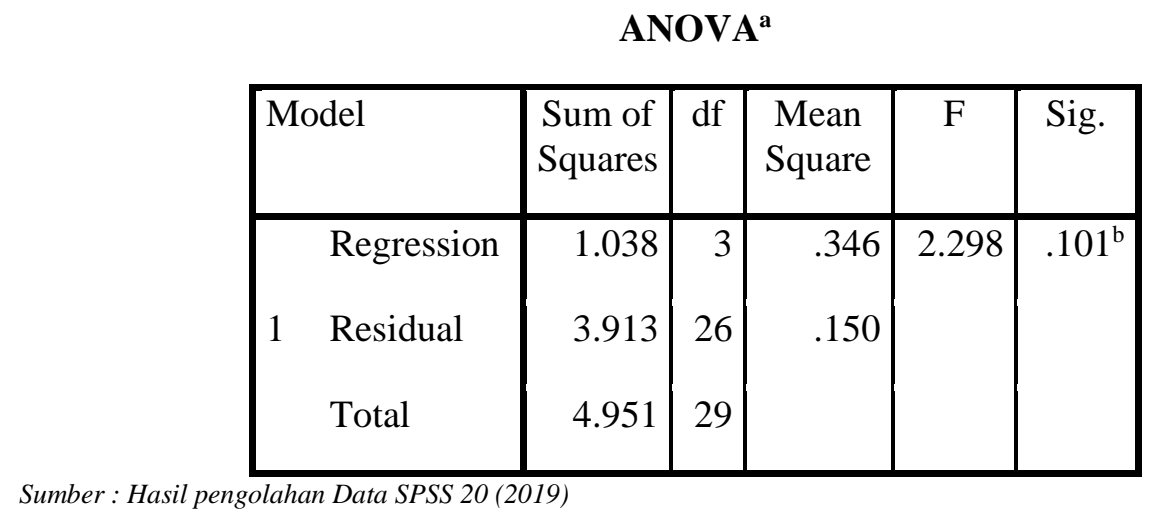

Dari tabel 3 terlihat bahwa nilai signifikasi $\mathrm{F}=0,101$ dimana nilai signifikasi lebih besar dari $\alpha=0,10$. Artinya H0 diterima dan Ha ditolak. Maka sesuai dengan dasar pengambilan keputusan dalam Uji F dapat disimpulkan bahwa Ha ditolak atau mudharabah, murabahah dan musyarakah tidak berpengaruh secara simultan terhadap Return on Asset.

Tabel 4. Hasil Koefisien Determinasi

\section{Model Summary ${ }^{b}$}

\begin{tabular}{|l|l|c|c|c|l|}
\hline Model & $\mathrm{R}$ & $\begin{array}{c}\mathrm{R} \\
\text { Square }\end{array}$ & $\begin{array}{c}\text { Adjusted } \\
\mathrm{R} \text { Square }\end{array}$ & $\begin{array}{c}\text { Std. } \\
\text { Error of } \\
\text { the } \\
\text { Estimate }\end{array}$ & $\begin{array}{l}\text { Durbin- } \\
\text { Watson }\end{array}$ \\
\hline
\end{tabular}




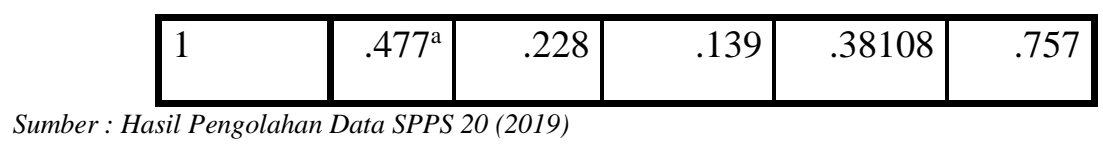

Berdasarkan tabel 4 diatas, diperoleh nilai Adjusted R Square sebesar 0,228, hal ini berarti menunjukan bahwa proporsi pengaruh mudharabah, murabhah dan musyarakah sebesar $22,8 \%$. Artinya mudharabah, murabahah dan musyarakah terhadap ROA sebesar $22,8 \%$ sedangkan sisanya $77,2 \%$ dipengaruhi oleh variabel lain yang tidak ada dalam model regresi linear.

\section{Kesimpulan}

Berdasarkan hasil penelitian tentang pengaruh pembiayaan murabahah, mudharabah dan musyarakah terhadap profitabilitas (ROA) pada Bank BRI syariah dapat ditarik kesimpulan sebagai berikut:

1. Pembiayaan Mudharabah berpengaruh positif terhadap profitabilitas (ROA) pada bank BRI Syariah. Yang berarti setiap peningkatan pembiayaan mudharabah yang diberikan oleh bank BRI Syariah akan meningatkan profitabilitas. Hal ini kemungkinan disebabkan oleh banyaknya pembiayaan mudharabah yang dikeluarkan oleh bank syariah. Tingkat risiko yang rendah pada pembiayaan mudharabah menyebabkan banyaknya peminat mudharib atas pembiayaan ini. Tingkat risiko yang rendah ini juga menyebabkan perbankan syariah lebih senang untuk menyalurkan pembiayaan mudharabah.

2. Pembiayaan Murabahah berpengaruh positif terhadap profitabilitas bank BRI Syariah. Yang berarti setiap peningkatan pembiayaan murabahah yang diberikan oleh bank syariah akan meningatkan profitabilitas dari bank syariah yang bersangkutan. Hal ini kemungkinan disebabkan oleh banyaknya pembiayaan murabahah yang dikeluarkan oleh bank syariah. Tingkat risiko yang rendah pada pembiayaan murabahah menyebabkan banyaknya peminat atas pembiayaan ini. Tingkat risiko yang rendah ini juga menyebabkan perbankan syariah lebih senang untuk menyalurkan pembiayaan murabahah kepada nasabah dikarenakan kemungkinan kerugian yang terjadi pada pembiayaan murabahah lebih kecil.s

3. Pembiayaan musyarakah memiliki pengaruh yang negatif terhadap profitabilitas. Yang berarti setiap peningkatan pembiayaan musyarakah akan menurunkan profitabilitas dari bank syariah yang bersangkutan. Hal ini kemungkinan disebabkan oleh kerugian yang didatangkan dari bisnis-bisnis yang dijalankan oleh mudharib. Mengingat setiap peningkatan pembiayaan pada bank syariah akan meningkatkan risiko pembiayaan. Musyarakah memiliki tingkat risiko yang tinggi. Kurangnya pemahaman terhadap risiko-risiko yang akan dihadapi akan mengakibatkan meningkatkan kemugkinan terjadinya kerugian.

\section{E. Saran}

\section{Saran Teoritis}

Variabel yang digunakan dalam penelitian ini hanya dapat menjelaskan saja sehingga diharapkan untuk penelitian selanjutnya dapat menambahkan variabel yang lain dalam penelitian ini yang bisa dan dapat membuat variabel independennya berpengaruh besar.

\section{Saran Praktis}

Perlu adanya strategi yang dilakukan oleh Bank Umum Syariah dalam meningkatkan prifitabilitas bank sehingga diharapkan dengan adanya kenaikan komposisi pembiayaan dapat meningkatkan profitabilitas bagi bank. Dan Bank Umum Syariah perlu meningkatkan lagi pembiayaan dalam bentuk pembiayaan jual beli (murabahah) dan bagi hasil (mudharabah dan musyarakah), karena bagaimanapun juga pembiayaan bagi hasil dan jual beli merupakan produk unggulan pada bank syariah. 


\section{Daftar Pustaka}

[1] Akerta, A., Bisri, H., \& Murabahah, M. (2019). Pengaruh Pendapatan Bagi Hasil Mudharabah dan Pendapatan Margin Murabahah Terhadap Laba Perusaha di PT . Bank Syariah Bukopin Periode 2013-2016 The Effect of Mudharabah Profit Sharing and Murabahah Margin Income on at PT . Bank Syariah Bukopin Period 2013-2016. 2(2).

[2] Amalia, S., \& Hapsari, A. A. (2019). Analisis Credit Risk Pembiayaan Berbasis Bagi Hasil Mudharabah dan Musyarakah terhadap Tingkat Profitabilitas (ROA) Bank Umum Syariah Devisa PerTriwulan (Periode 2016-2017). I(1), 32-38.

[3] Andi. 2014. Analisis Data Penelitian dengan SPSS 22. Yogyakarta: Andi Yogyakarta dan Wahana Komputer Semarang.

[4] Ekawati, K. (2019).Faktor-Faktor yang Mempengaruhi Tingkat Margin Mudharabah Pada Industri Perbankan Syariah Periode 2012-2017. 50-67.

[5] Ekonomi, G. S. (2017). Analisis pengaruh pembiayaan murabahah, mudharabah, musyarakah, dan ijarah terhadap tingkat laba bersih pada bank muamalat \& bank syariah mandiri periode 2011-2016.

[6] Ghozali, Imam. (2006). Aplikasi Analisis Multivariate dengan SPSS (Ed.Ke-4). Semarang: Universitas Diponegoro.

[7] Ghozali, Imam. (2013). Aplikasi Analisis Multivariate dengan Program SPSS (Ed. Ke-7). Semarang: Universitas Diponegoro 